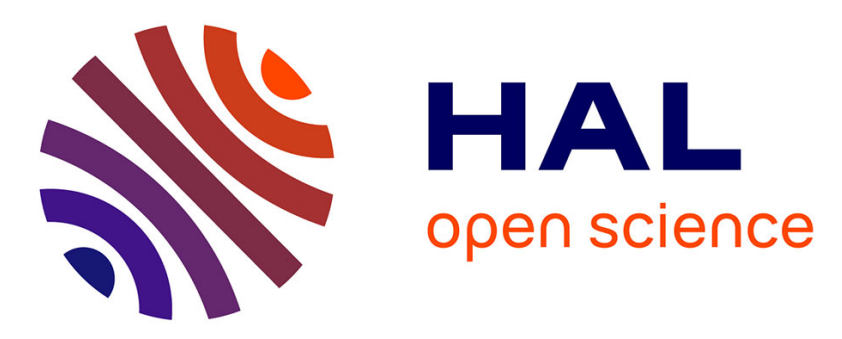

\title{
Urinary Disorders and Marfan Syndrome: A Series of 4 Cases
}

\author{
Claire Hentzen, Nicolas Turmel, Camille Chesnel, Frédérique Le Breton, \\ Samer Sheikh Ismael, Gérard Amarenco
}

\section{To cite this version:}

Claire Hentzen, Nicolas Turmel, Camille Chesnel, Frédérique Le Breton, Samer Sheikh Ismael, et al.. Urinary Disorders and Marfan Syndrome: A Series of 4 Cases. Urologia Internationalis, 2018, 101 (3), pp.369-371. 10.1159/000484696 . hal-02022798

\section{HAL Id: hal-02022798 https://hal.sorbonne-universite.fr/hal-02022798}

Submitted on 18 Feb 2019

HAL is a multi-disciplinary open access archive for the deposit and dissemination of scientific research documents, whether they are published or not. The documents may come from teaching and research institutions in France or abroad, or from public or private research centers.
L'archive ouverte pluridisciplinaire HAL, est destinée au dépôt et à la diffusion de documents scientifiques de niveau recherche, publiés ou non, émanant des établissements d'enseignement et de recherche français ou étrangers, des laboratoires publics ou privés. 
Title: Urinary disorders and Marfan syndrome: series of 4 cases

Claire Hentzen $^{1,2}$, Nicolas Turmel ${ }^{1,2}$, Camille Chesnel $^{1,2}$ MD, Frederique Le Breton ${ }^{1,2}$ MD, Samer Sheikh Ismael ${ }^{1,2} \mathrm{MD}$, Gérard Amarenco ${ }^{1,2} \mathrm{MD}-\mathrm{PhD}$

${ }^{1}$ GREEN GRC-01 UPMC: Group of clinical REsEarch in Neurourology, University Pierre and Marie Curie, 75005 Paris, France

${ }^{2}$ Department of Neuro-urology, Tenon Hospital, APHP, Paris, France

Corresponding author:

Hentzen Claire

Hôpital Tenon

Service de Neuro-Urologie

4 Rue de la Chine

75020 Paris, France

Tel: $+33(0) 1-56-01-79-54$

Fax: + 33(0)1-56-01-72-30

Email: claire.hentzen@hotmail.com

Key words: Marfan syndrome, Lower urinary tract symptoms, Overactive bladder, Neurogenic bladder, Aortic aneurysm 


\begin{abstract}
Marfan syndrome is a genetic disease, responsible for cardiovascular, eye and musculoskeletal damages. Urinary disorders are not common.

We present four cases of chronic urinary tract symptoms, with two different pathophysiological processes. Three patients present spinal cord infarct following aortic dissection surgery. They suffer from overactive bladder with detrusor overactivity and detrusor-sphincter dyssynergia. One patient complains of voiding dysfunction, possibly related to dural ectasia.
\end{abstract}

Although a rare outcome, urinary disorders may appear in Marfan syndrome, by occurrence of surgical complications in aortic surgery or possibility of sacral nerve root compression. If so, medical care is necessary to prevent uro-nephrological complications. 


\section{Introduction}

Marfan syndrome is an autosomal dominant disorder, secondary to mutation in fibrillin-1 in most cases. Its clinical description includes cardiovascular, eye and musculoskeletal damages[1]. The diagnosis in adults is based on revisited Ghent criteria, in which diagnosis is confirmed by association of aortic disease and ectopia lentis[2].

Urinary disorders are not common in Marfan syndrome and we have not found in the literature any description of chronic urinary tract symptoms in this population. Yet, secondary to vascular or neurological complications, their occurrence seems to be possible. We present a series of 4 cases of patients with Marfan syndrome following in neuro-urology department for urinary disorders. Two distinct mechanisms can be described. The first one is occurrence of medullary infarct during aortic dissection or surgery. The second one is a suspicion of symptomatic myelomeningocele due to dural ectasia, in a patient complaining of urinary retention.

\section{Case report}

The first patient is a 47-year-old man suffering from Marfan syndrome. He had a spinal cord infarct in T9-T10 following prosthetic aortic replacement surgery, leading to lower limb monoplegia. He suffered from voiding dysfunction with urinary stuttering, feeling of incomplete voiding and urethral anesthesia. Moreover, he experimented urgency and nocturia without leaks. Due to neurological etiology, he also had chronic constipation and erectile dysfunction. His urodynamic assessment demonstrated overactive detrusor with involuntary detrusor contractions at $150 \mathrm{ml}$ and detrusor-sphincter dyssynergia. However, he could completely empty his bladder by pushing and Crede maneuver. Treatment associated anticholinergic and alpha blocker drugs, with a good success on symptoms and quality of life. 
Five years after the surgery, symptoms progressively improved and disappeared, and the patient stopped all treatments with clinical and urodynamic good balance.

The second patient is a 50-year-old man with Marfan syndrome, presenting monoplegia of right lower limb, T10 sensitive level and pyramidal syndrome, secondary to spinal cord infarct following aortic dissection. He had an overactive bladder syndrome with detrusor overactivity, associated with detrusor-sphincter dyssynergia. He also had constipation, absence of anal voluntary contraction and erectile dysfunction. Renal ultrasound revealed a bilateral upper tract dilation, which required antimuscarinics and self-catheterization. Overactive bladder was well controlled by this treatment, with normalization of renal dilation on ultrasound.

The third patient is a 46-year-old woman with Marfan syndrome who presented a conus medullaris infarct secondary to a revision surgery 3 years after aortic dissection. She had urinary retention that spontaneously improved 4 months later. She also suffered from chronic constipation. Urodynamic assessment revealed detrusor overactivity from $130 \mathrm{ml}$ of filling. She was initially treated by alpha blockers but after one febrile urinary tract infection, antimuscarinics and self-catheterization ( 3 to 4 per day) were introduced. This treatment was effective to control detrusor overactivity and overactive bladder symptoms which were secondarily appeared.

The last patient is a 24-year-old man with no history of spinal cord infarct. He complained of voiding dysfunction appeared suddenly, with two consecutive acute urinary retentions. Since these episodes, he performed self-catheterization when voiding was impossible. He also experimented constipation but no erectile dysfunction. Secondary to Marfan syndrome, he had important scoliosis with lumbar sacral dural ectasia (Figure 1). Urodynamics revealed 
anesthetic bladder with no voluntary or involontary detrusor contraction. Perineal electromyography was within the normal limits, without sacral latency abnormalities.

\section{Discussion:}

Urinary disorders are not described in Marfan syndrome except isolated case of urinary retention on dural ectasia external compression[3] and possibility of increased incontinence in women due to connective tissue abnormalities[4].

Here we report two new mechanisms to explain lower urinary tract symptoms in this disease. The first mechanism is the occurrence of spinal cord infarct as a complication of aortic surgery or dissection. Indeed, more than one third of patients with Marfan syndrome will be operated on an aortic event in their life (aortic dissection or preventively in aortic dilation[5]). Even if morbidity during this surgery decreases with novel techniques, spinal cord infarct is still one of their complication [6], and Marfan syndrome is a predictor of its occurence[7]. In this case, urinary disorders are almost systematically found, since medullar integration of urinary functions is in T12-L2 and S2-S4 metameres. It is necessary to take into account these symptoms because of risks of uro-nephrological complications, secondary to detrusor overactivity and detrusor-sphincter dyssynergia.

The second mechanism is the possible role of dural ectasia, with direct sacral root compression. Dural ectasia is defined as a ballooning or a widening of the dural sac and nerve root sleeves. It may be associated with anterior sacral meningocele. In most cases, this malformation is totally asymptomatic. One case of cauda equina syndrome in a rheumatologic pathology have been described[8]. However, interpretation has to be discussed, since dural ectasia is common in Marfan syndrome, with more that $60 \%$ of prevalence[1] and size increasing with age. Initially a major criterion for diagnosis, dural ectasia is now related in 
second plan, due to variability of descriptions and occurrence in other pathologies of connective tissue[2]. There is less evidence of a pathological role of dural ectasia: it should be associated with back pain[9] and can induce rare case of intracranial hypotension[10].

\section{Conclusion:}

Although a rare outcome, urinary disorders may appear in Marfan syndrome, by occurrence of surgical complication in aortic surgery or possibility of sacral nerve root compression. If so, medical care is necessary to prevent uro-nephrological complications.

\section{Conflicts of interest: none}


Figure 1: severe scoliosis and dural ectasia (patient 4)

Left picture is a 3D reconstruction Magnetic Resonance Imaging (MRI) in frontal plan. Right picture is a T2 sequence MRI in sagittal plan.

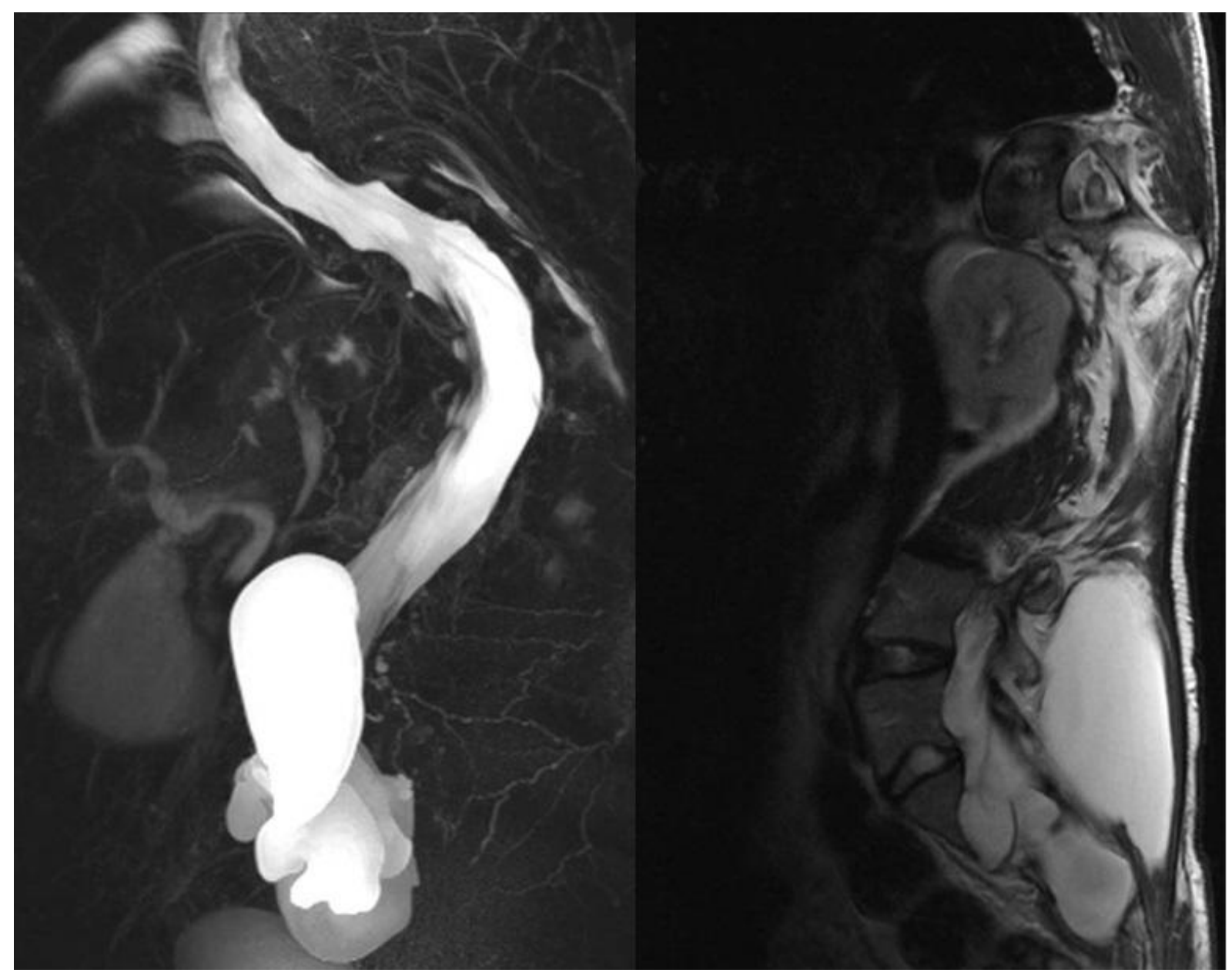




\section{References:}

1 Dean JCS: Marfan syndrome: clinical diagnosis and management. Eur J Hum Genet EJHG 2007;15:724-733.

2 Loeys BL, Dietz HC, Braverman AC, Callewaert BL, De Backer J, Devereux RB, et al.: The revised Ghent nosology for the Marfan syndrome. J Med Genet 2010;47:476-485.

3 Stone JG, Bergmann LL, Takamori R, Donovan DJ: Giant pseudomeningocele causing urinary obstruction in a patient with Marfan syndrome. J Neurosurg Spine 2015;23:77-80.

4 Chan SSC, Chan DKH, Pang SMW, Lam STS, Lao TTH, Choy K-W: Urinary incontinence should be added to the manifestation in women with Marfan syndrome. Int Urogynecology J 2010;21:583-587.

5 Groth KA, Stochholm K, Hove H, Kyhl K, Gregersen PA, Vejlstrup N, et al.: Aortic events in a nationwide Marfan syndrome cohort. Clin Res Cardiol Off J Ger Card Soc 2017;106:105-112.

6 Gialdini G, Parikh NS, Chatterjee A, Lerario MP, Kamel H, Schneider DB, et al.: Rates of Spinal Cord Infarction After Repair of Aortic Aneurysm or Dissection. Stroke 2017; DOI: 10.1161/STROKEAHA.117.017071

7 Trimarchi S, Tolenaar JL, Tsai TT, Froehlich J, Pegorer M, Upchurch GR, et al.: Influence of clinical presentation on the outcome of acute $\mathrm{B}$ aortic dissection: evidences from IRAD. J Cardiovasc Surg (Torino) 2012;53:161-168.

8 Ha S-W, Son B-C: Cauda equina syndrome associated with dural ectasia in chronic anlylosing spondylitis. J Korean Neurosurg Soc 2014;56:517-520.

9 Ahn NU, Sponseller PD, Ahn UM, Nallamshetty L, Kuszyk BS, Zinreich SJ: Dural ectasia is associated with back pain in Marfan syndrome. Spine 2000;25:1562-1568.

10 Abu Libdeh A, Matsumoto JA, Dhamija R: Teaching NeuroImages: Intracranial hypotension in a patient with Marfan syndrome. Neurology 2016;87:e40-41. 